\title{
Using Rhinoceros Plugins Grasshopper and Ladybug to Assess BIPV Façades in Brasília
}

\author{
Jader de Sousa Freitas ${ }^{1}$, Joára Cronemberger ${ }^{1}$, Raí Mariano Soares ${ }^{1}$ \\ ${ }^{1}$ LACAM Laboratory of Environmental Control - Faculty of Architecture and Urbanism, \\ University of Brasília, Campus Universitário Darcy Ribeiro, Brasília, Brazil, 70910-90 \\ e-mail: jaderjsf@gmail.com
}

\begin{abstract}
The diffusion of BIPV systems involves the education of young professionals, nowadays used to design tools that should allow integrating this possibility since first sketches of buildings. However, most tools are more suitable for designs in later stages. This paper presents a feasibility study using Rhinoceros application software and plugins Grasshopper and Ladybug to assess BIPV design in institutional buildings in Brasília, Brazil. The research method consisted using only those application tools for designing, simulating and analyzing PV proposals. The most favorable results were found in the proposals for taller buildings, with larger effective area available for PV integration. The results of this work may serve as a basis for future design tools development and highlights the importance of the integration between three-dimensional modelling software and the simulation tools of BIPV systems.
\end{abstract}

\section{Introduction}

In the current context of the growing search for alternative renewable energy sources, photovoltaic systems integrated to building envelopes (BIPV) are one of the most exploited technologies in the world. It is a sophisticated means of producing electricity in the site, directly from solar radiation and does not cause significant environmental damage (IEA, 1995). However, the vast majority of those systems (above $90 \%$ ) are located outside the tropics of the planet, where the solar resource is not so abundant (Nobre, 2015).

BIPV (Building Integrated Photovoltaics) and BAPV (Building Attached Photovoltaics) systems appropriates their envelopes, converting them into power plants. Thus, the energy produced can supply this building with part or all of the energy required for its operation, requiring no extra area or additional infrastructure facilities. It can therefore be used in the urban environment, close to the consumption point, avoiding transmission and distribution (T\&D) infrastructure losses, specially desirable in a extensive distances, as Brazil (Rüther and Zilles, 2011).

According to studies led by Cronemberger et al. (2012), the Brazilian territory is characterized by high levels of solar irradiation with a wide range of possible orientations and inclinations, making BIPV systems suitable for roofs and façades in various types of buildings. In façades with elements tilted between $40^{\circ}$ and $90^{\circ}$ the solar potential represents between $60 \%$ and $90 \%$ of the maximum global solar irradiation, making them as good options for PV integration. Vertical $90^{\circ}$ façades may have nevertheless enough incident radiation, mostly for North orientations in cities with latitudes between $15^{\circ} \mathrm{S}$ and $30^{\circ} \mathrm{S}$, as Brasilia (Latitude $\left.15,6^{\circ}\right)$. Moreover, Brazil counts with a favorable NetMetering scheme regulated since 2012 which aims to integrate energy from renewable sources such as photovoltaics into public grid (ANEEL, 2015). Other studies have concluded for the technical and economic viability of distributed PV systems in many regions of this country (Gomes et al, 2018).

Brasília, located in the center-west region of Brazil, has an average annual insolation of 2368,3 hours (INMET). In the central region of the city there is a considerable number of modern institutional buildings inserted in a climate context conducive to the integration of PV systems. Oliveira and Amorim (2017) identified architectural characteristics of commercial and institutional buildings in the center of Brasília, which suggest the potential of their envelopes for generating electricity.

The diffusion of PV technology necessarily involves the education of young professionals, accustomed to tools that should allow integrating this possibility even in the first designs phases of a building. It is precisely in these early stages that decisions made may affect directly the BIPV possibilities. Approximately $80 \%$ of the design decisions that influence a building's energy performance are made by architects in the early design phase; the remaining $20 \%$ are made by engineers at the later phases of design (IEA Task 41, 2010). However, in general, most of the sizing and calculation tools of PV systems are more suited for detailed design rather than for early design phase (IEA Task 41, 2010).

To consider the integration of PV systems since the first stages of design, it is necessary to count with reliable tools that allow a basic FV energy simulation linked to $3 \mathrm{D}$ modeling software are emerging. The present work aims to examine the use of the widespread used modeling software Rhinoceros and plugins Grasshopper and Ladybug, in the feasibility study for BIPV and BAPV façades in retrofits of institutional buildings in the central zones of Brasília. The results of the analysis of some real buildings, both from an energetic and an architectural point of view, are presented. 


\section{Methods}

The research method consisted in the design, simulation and analysis of BIPV systems in 7 (seven) institutional public buildings in the central zone of Brasília. The constructive data and power consumption profiles of the chosen buildings were obtained from the partial results of the research project underway at the Laboratory of Environmental Comfort of the Faculty of Architecture and Urbanism of the University of Brasília (LACAMFAU-UnB), entitled "Monitoring and compiling data for thermal performance, natural light and energy efficiency assessments in buildings and urban areas".

Initially, the most suitable façades for PV integration were identified, considering near shadings and available solar irradiation. Afterwards, we proposed BIPV design alternatives, which have been used to carry out simulations of electricity generation for each of the façades in selected buildings. Finally, the energy balance was calculated, considering the annual consumption real data. All simulations and drawings were performed using Rhinoceros and plugins Grasshopper and Ladybug. The climatic dataset used was extracted from the EPW (EnergyPlus Weather File) and SWERA data (Solar and Wind Energy Resource Assessment).

For energy compensation, Net-Metering scheme regulated by National Regulatory Agency for Electricity (RN482/ANEEL) was used. This mechanism establishes that a consumer connected to a public grid can export energy to it to later consumption, in a monthly basis. There is only energy exchange, where the distribution network work as limitless storage system (ANEEL, 2015). So, each $\mathrm{kWh}$ generated in-site is exported to grid to be later compensated with another $\mathrm{kWh}$ imported from there.

\section{Buildings selection}

The architecture of Brasília is very marked by the presence of modernist characteristics. A large part of the city's buildings has up to 6 floors, ground level with pilotis and a rectangular projection. For a better effect in the research, the selected buildings obeyed the criterion of having more varied architectural typologies and similar characteristics of energy consumption. In this way, public institutional buildings located in the center of Brasília (Figure 1) were chosen.

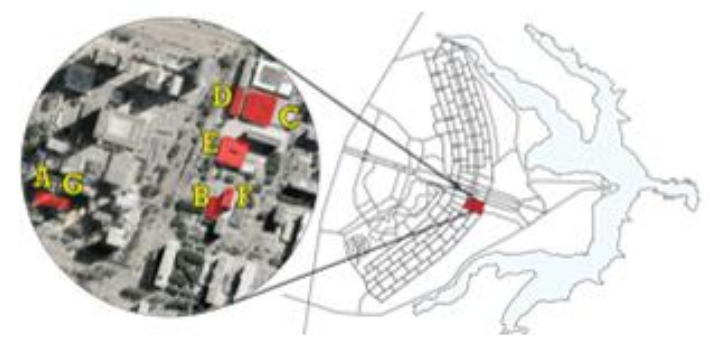

Figure 1: Building's in city center, Brasilia, Brazil.

They were classified in three groups: up to 2 floors, between 3 and 6 floors, and above 6 floors (Table 1). For the purposes of this study, the number of floors does not include basement, used as parking lots, as far as the classification only intends to compare the building's potential surfaces for energy production.

Table 1: classification of buildings.

\begin{tabular}{|c|c|}
\hline Classification groups & Names \\
\hline Up to 2 floors & Buildings A and B \\
\hline Between 3 and 6 floors & Buildings C, D and E \\
\hline Above 6 floors & Buildings F and G \\
\hline
\end{tabular}

\section{Generation of 3D models and identification of the most suitable surfaces for BIPV systems}

Rhinoceros was chosen because of the existing knowledge on the part of the researchers about its tools, the easiness of creating 3D models, its wide diffusion among professional and architecture students. Besides that, many application plugins were developed to perform the desired PV simulations. It also allows modelling geometries with great complexity as well as to import different file formats and convert them into the 3dimension proprietary format. This means a high user flexibility because it is possible to import a physical model already available in other formats as well as to create a new one, thus bypassing the need for a GIS model (Costanzo et al., 2018).

The buildings and their immediate surroundings were modeled based on plants, sections and façades obtained from the LACAM research project database and satellite images taken from geographical web-database from Secretariat of State for Territory and Housing Management of the Federal District (SEGETH-DF).

After virtual models were completed, the Grasshopper and Ladybug plugins were used to perform solar irradiation simulations. Grasshopper is a graphical algorithm editor integrated with Rhino's 3-D modelling tools. Because it is a parametric modeler connected to $3 \mathrm{D}$ rendering software, the plugin has been extensively utilized in the field of virtual modelling. Parametric modelling refers to the automated parameter-based generation of any project elements. This means that the generation and variation of the elements within a project is controlled with specific algorithm generated rule-sets (Eltaweel and SU, 2017). Ladybug is a plugin of Grasshopper capable of performing simulations in the area of environmental design based on the geometry generated in Rhinoceros or Grasshopper and the climate file EnergyPlus weather file (EPW) of the desired location. In addition, this environmental information can be connected parametrically to the project data in order to understand the influence of weather and location on the studied project. (Eltaweel and SU, 2017).

The input parameters and data required to perform the solar irradiation simulations were the Brasília climate EPW file; the geometry for which radiation analysis will be conducted; the context geometry that could block sunlight to the test geometry; the analysis period; a vector to be used as a true North direction and the average size of a grid cell for radiation analysis on the testing surfaces. 
The data generated with the simulations were the amount of radiation in $\mathrm{kWh} / \mathrm{m}^{2}$ falling on the input test geometry at each of the test points; a colored mesh of the test geometry representing the radiation in $\mathrm{kWh} / \mathrm{m}^{2}$ falling on this input geometry and the total radiation in $\mathrm{kWh}$ falling on the input test geometry.

Through the results obtained, it was possible to identify the most favorable surfaces to BIPV system in each building.

\section{Types of PV integration}

From the simulations of irradiation and evaluation of the most favorable surfaces for PV integration, solutions were proposed taking into account the architecture of the building itself, as well as its immediate context. The decision regarding slope and orientation of the modules was based on the annual global irradiation analysis chart proposed by Cronemberger et al (2012) (Figure 2).

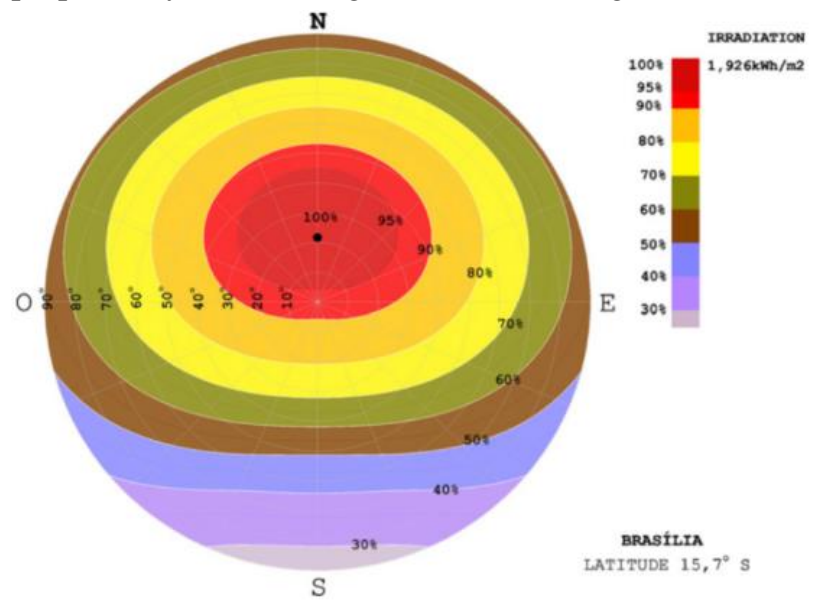

Figure 2: Graph of annual global irradiation in Brasília, upon all tilts and azimuths. Source: Cronemberger et al (2012)

The criteria for choosing the modules to be installed were cell type, efficiency and dimensions. In the façade design proposals, aesthetics was an important factor for the choice of the modules, either customized or off-theshelf market characteristics. Customized modules have the advantage of having greater flexibility in their dimensions, thus covering a surface with a greater effective area, increasing the power potential of the system. The characteristics of the market type module chosen are presented in Table 2. Efficiency used in the simulations was the same for both cases.

Table 2: Characteristics of the modules used in the simulations

\begin{tabular}{|l|c|}
\hline Dimension $(\mathbf{c m})$ & $99,2 \times 165$ \\
\hline Width $(\mathbf{c m})$ & 3,5 \\
\hline Area $\left(\mathbf{c m}^{2}\right)$ & 16368 \\
\hline Active Percentage of Module & $90 \%$ \\
\hline Efficiency & $18,02 \%$ \\
\hline Nominal Maximum Power $(\mathbf{W})$ & 295 \\
\hline Temperature Coefficient $($ Pmax) & $-0,50 \% /{ }^{\circ} \mathrm{C}$ \\
\hline $\begin{array}{l}\text { Nominal Module Operating } \\
\text { Temperature (NMOT) }\end{array}$ & $43 \pm 3^{\circ} \mathrm{C}$ \\
\hline Specifications & 60 Polycrystalline \\
& Silicon cells \\
\hline
\end{tabular}

\section{Grasshopper and Ladybug parameters}

After performing the three-dimensional representation of the integrated systems, available irradiance on modules surfaces and AC energy generation were simulated. The flat surfaces where the PV modules were applied and the geometries representing the surroundings were modeled on the Rhinoceros oriented with the correct azimuth according to each PV integration design proposal. The percentage of surfaces destined to receive the PV modules varied according to the type of module adopted. For market modules, the percentage used was consistent with the capacity to fill the area of the surfaces by modules of dimensions specified in Table 2. For customized modules, the percentage adopted was $100 \%$.

The Ladybug component that calculates the losses of the $\mathrm{PV}$ system and the transformation of DC power to AC is the "DC to AC derate factor." The losses considered in the simulations were the annual shading, where the value is calculated through the component "Sunpath Shading" based on the geometries of the 3D model. The remaining component of the input "DC to AC derate factor" were left with the default values (age, snow, wiring, soiling, and mismatch connections) or marked as 0 (availability, nameplate rating and light induced degradation).

The characteristics of PV modules used in the simulations are described in Table 2 . In addition to these, it was necessary to inform the mounting configuration of the modules and the percentage of area of active modules (percentage of the module's area excluding module framing and gaps between cells). The configuration used was "Open rack" (ground mount array, flat / sloped roof array that is tilted, pole-mount solar panels, solar canopies, BIPV installations with sufficient backside airflow) and the percentage of active module area used was $90 \%$.

The data obtained with the simulations were: AC energy for each hour during a year; total AC power output for a whole year; an average AC power output per day for a whole year; DC power output of the PV array for each hour during a year; total radiation per hour; cell temperature for each hour during year; PV surface tilt angle; PV surface azimuth angle and system size.

With the data obtained in the simulations, energy balance for each building was calculated, considering the Net-Metering RN482/ANEEL regulation.

\section{Results}

Given the large number of results obtained through the adopted methodology, the results are presented in detail for Building $G$, whilst for the others only the final results are later exposed and analyzed.

Building $G$ has façades with large glazed areas and azimuths of $16,57^{\circ}, 106,57^{\circ}, 196,57^{\circ}$ and $286,57^{\circ}$. 

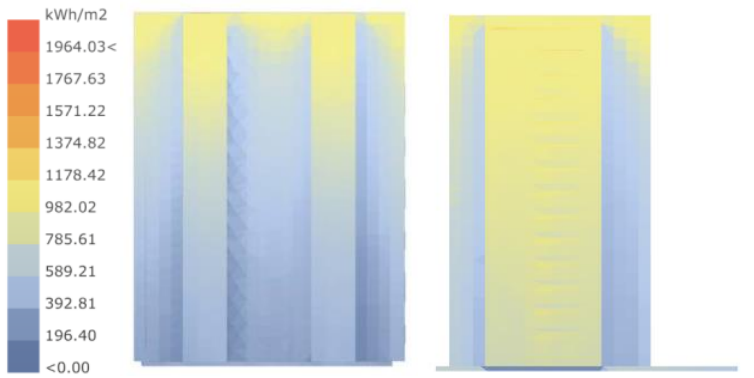

Figure 3: Building G - Availability of annual irradiation on façades 1 (North) and 2 (West).
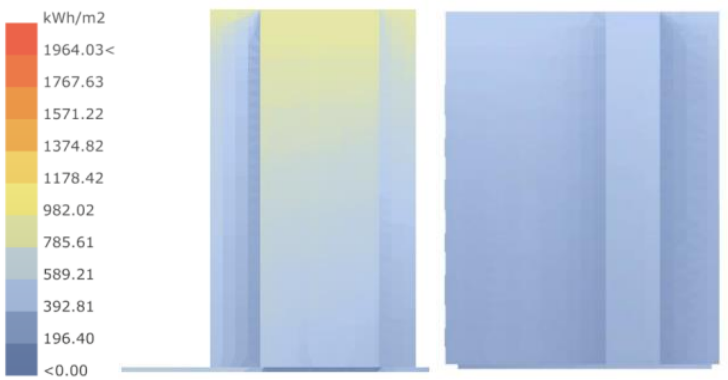

Figure 4: Building $G$ - Availability of annual irradiation on façade 3 (East) and 4 (South).

There are no sun shading elements on any of the façades. Regarding the surrounding context, Building $G$ receives partial shadowing of other buildings to the north and east, resulting that North, West have the most suitable façades to produce energy (Figures 3 and 4), receiving yearly $700-1.000 \mathrm{kWh} / \mathrm{m}^{2}$ and up to $897.789,52 \mathrm{kWh}$ in the whole façade surface (Table 3 ).

Table 3: Solar irradiation for $G$ Building façades

\begin{tabular}{|l|c|c|}
\hline Façade & Azimuth & Solar irradiation $(\mathbf{k W h}$ /year) \\
\hline North & $16,57^{\circ}$ & $897.789,52$ \\
\hline South & $286,57^{\circ}$ & $573.763,19$ \\
\hline East & $106,57^{\circ}$ & $429.535,62$ \\
\hline West & $196,57^{\circ}$ & $489.360,79$ \\
\hline
\end{tabular}

Based on the results obtained, East, North and West façades showed to be favorable to receive PV systems (Figure 5, indicated in red):
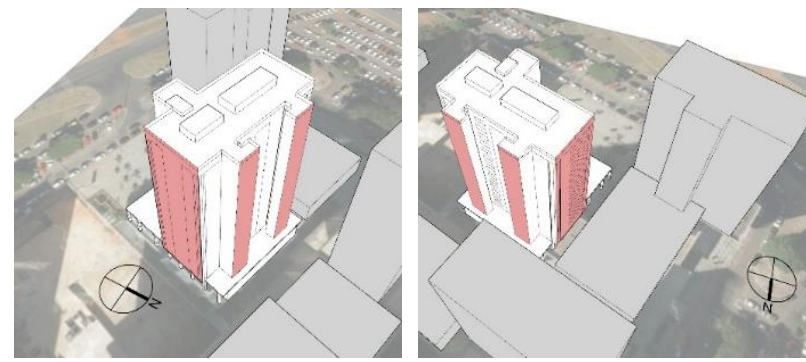

Figure 5: More favorable surfaces for PV integration.

The available irradiance data on the building surfaces made possible the following PV integration proposals:

Design 1 - PV modules designed to serve also as sun shading elements in North, West and East façades, $20^{\circ}$ tilted (Figure 6):

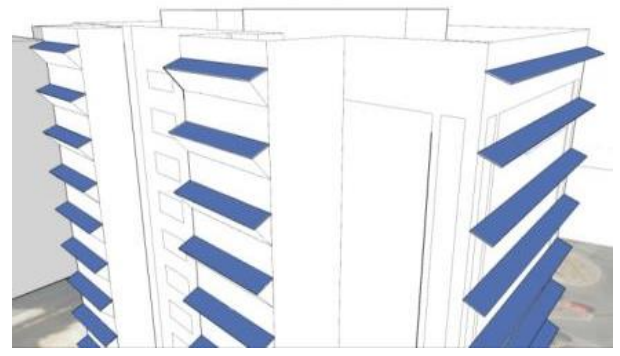

Figure 6: Design 1 for photovoltaic integration in façades of Building $G$.

Design 2 - PV modules designed to be also sun shading elements in North, West and East façades, but now tilted from $20^{\circ}$ to $90^{\circ}$ (Figure 7 ):
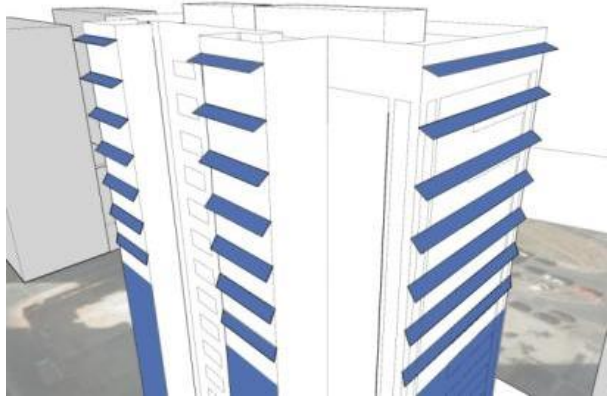

Figure 7: Design 2 for photovoltaic integration in façades of Building $G$.

Design 3 - PV modules designed as double skin façades North, West and East oriented, with some level of transparency (Figure 8):

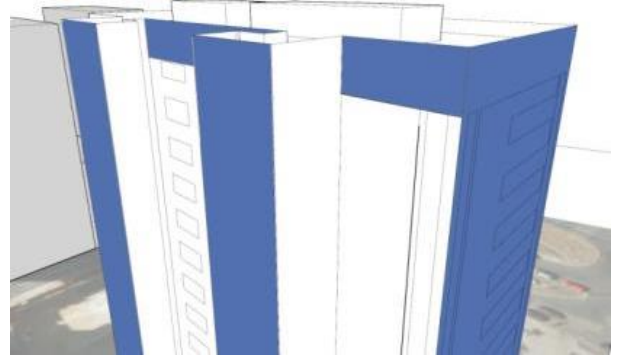

Figure 8: Design 3 for PV integration in façades of Building $G$.

Due to the different design options, those with more area available to install nominal power presented better energy balance, from $3,16 \%$ up to $8,05 \%$. Customized PV models' results were always slightly better rather than market modules, due to a bigger area for PV cells (Table 4).

Table 4: Energy balance results for Building G(\%)

\begin{tabular}{|l|c|c|}
\hline \multicolumn{3}{|c|}{ Energy balance (\%) } \\
\hline & Market PV & Custom PV \\
\hline Design 1 & 4,76 & 5,10 \\
\hline Design 2 & 3,16 & 3,35 \\
\hline Design 3 & 7,58 & 8,05 \\
\hline
\end{tabular}

The same design and simulation steps were taken to all building types. Best energy balance results are exposed 
in Table 5. Some of them were not considered suitable to receive PV modules into their façades, due to the shadowing, either self provoked or from neighboring buildings.

Table 5: Best energy balance results for all building types $(\%)$

\begin{tabular}{|c|c|c|c|c|c|c|}
\hline \multicolumn{2}{|c|}{ Up to 2 floors } & \multicolumn{3}{|c|}{ From 2 to 6 floors } & \multicolumn{2}{c|}{ Above 6 floors } \\
\hline A & B & C & D & E & F & G \\
\hline$*$ & 2,66 & 5,50 & $*$ & 3,22 & 10,56 & 8,05 \\
\hline
\end{tabular}

(* façades not suitable to $P V$ integration)

Overall, simulations calculated from $2,66 \%$ up to $10,56 \%$ of energy balance, higher proportions for taller buildings. It happened because they are not so affected by shading in this central urban area of city. Figures 9 to 12 show some of their design integration typologies - PV ventilated double skin façades and sun shading devices.

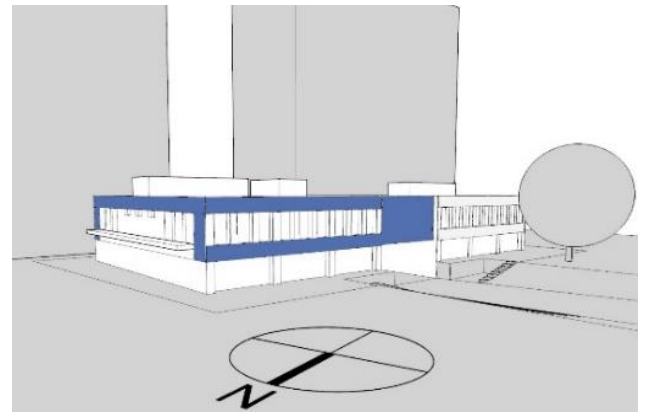

Figure 9: Design for PV integration in the façades of Building $B-P V$ ventilated double skin façades.

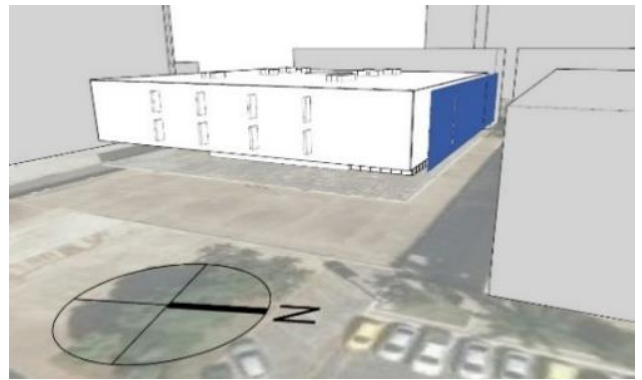

Figure 10: Design for PV integration on the façades of Building $C-P V$ ventilated double skin façades

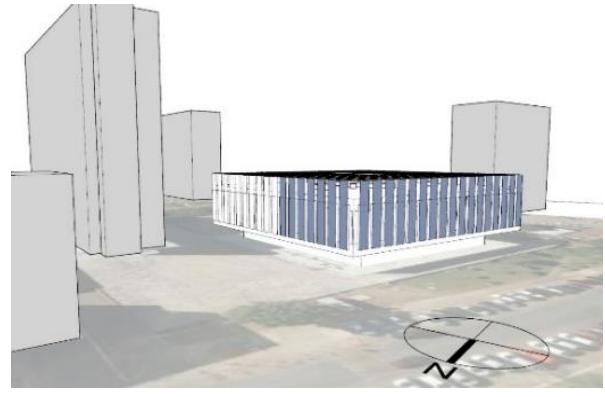

Figure 11: Design for PV integration on the façades of Building E-PV ventilated double skin façades.

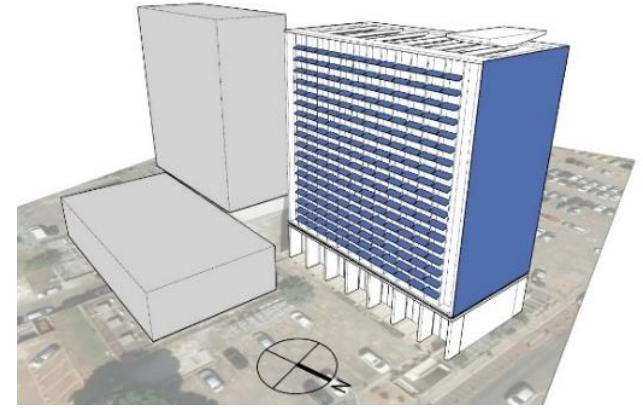

Figure 12: Design for PV integration in the façades of Building $F-P V$ ventilated double skin façades and sun shading devices.

\section{Discussion}

To use this methodology of simulation in some project it is necessary to have knowledge in the areas of architecture, PV technology and basics of 3D modelling. A greater mastery of the Rhinoceros and Grasshopper modelling tools is not necessary for the early phases of a project, and it is possible to perform the simulations from simplified geometries.

During all phases of a project the time required to perform certain tasks is crucial to the progress of the work. Therefore, the time required to run the simulations is a factor of interest for the professionals in charge of each stage of a BIPV design project. Modeling a 3D design, organizing the components and data in grasshopper are tasks that depend on the level of knowledge and familiarity with the application by the person performing the simulations, so the execution time of these tasks was not counted. In general, the simulations ranged from 2 minutes to 6 hours. This variation was largely due to differences in geometry from one model to another. More detailed models with a larger number of surfaces required more simulation time. The possibility of joining the parametric design with the PV technology is a very interesting aspect for the choice of the software used in this methodology. Studies such as Jayathissa et al (2016) and Eltaweel and SU (2017) showed that there are a number of Grasshopper and Rhinoceros tools that can lead to innovative and aesthetically differentiated solutions that may increase the potential for energy generation, besides encouraging the creation of new technologies.

\section{Conclusion}

The methodology adopted in this paper highlights the importance of integrate three-dimensional modeling software to PV systems simulations tools. The software used in the study proved to be efficient in the objective of generating results for BIPV designs when retrofitting existing buildings. Due to the simplicity and easiness of learning, these tools are also useful in all phases of building design, especially in the early stages of design, when important decisions that affect PV energy possibility are taken. The choice for using them is more related to the knowledge required in architecture and PV issues, rather than the ability with the software itself. Therefore, professionals and students in both areas will 
not find significant difficulties to adopt them to design BIPV alternatives to new and existing buildings.

The results of the simulations showed that although the tilted modules used as sun-shading devices presented better performance in relation to the total available solar irradiation, BIPV arranged vertically could occupy more area of the façades, allowing to install higher nominal power.

Because they are located in an urban area, all the analyzed buildings presented a considerable shadowing provoked by neighboring buildings or high vegetation. This shading prevented the use of entire façades or even part of them to PV integration surfaces. With the results of energy generation obtained it was possible to verify that the taller the building, the greater the capacity to produce energy through PV modules installed in the façades. The most efficient typologies for the generation of energy were those that used the largest active area of photovoltaic cells. Vertical surfaces of tall buildings, equipped with customized modules with large percentage of effective photovoltaic area were the best energy producers.

Despite the high electricity consumption in the buildings studied, solar energy produced by the BIPV systems in façades managed to supply up to $10,56 \%$ of the annual consumption. This fact demonstrates that although it does not fully supply the energy consumption of a building, photovoltaic integration in façades is able to reduce considerable energy costs in institutional buildings. The adoption of energy efficiency strategies, like efficient air conditioning and lighting systems may increase this balance sheet.

\section{Acknowledgments}

The authors would like to thank: The Laboratory of Environmental Comfort of the Faculty of Architecture and Urbanism of University of Brasília (LACAM-FAU$\mathrm{UnB}$ ) for providing essential data for the making of this paper and the Research Support Fund (FAP-DF) for the aid provided to the research.

\section{References}

Agência Nacional de Energia Elétrica (ANEEL) (2015). Resolução Aneel $n^{\circ}$ 687/2015.

Constanzo, V.; Yao, R.; Essah, E.; Shao, L.; Shahrestani, M.; Oliveira, A.C.; Araz, M.; Hepbasli, A.; Biyik, E. (2018). A method of strategic evaluation of energy performance of Building Integrated Photovoltaic in the urban context. Journal of Cleaner Production $184,82-91$.

Cronemberger, Joára; Martín, Estefanía Caamaño; Sánchez, Sergio Vega (2012). Assessing the solar irradiation potential for solar photovoltaic applications in buildings at low latitudes - Making the case for Brazil. Energy and Buildings 55, 264 272.

Eltaweel, Ahmad; SU, Yuehong (2017). Parametric design and daylighting: A literature review. Renewable and Sustainable Energy Reviews 73,1086 $-1103$.

Gomes, P. Vilaça; Neto, N. Knak; Carvalho, L.; Sumaili, J.; Saraiva, J. T.; Dias, B. H.; Miranda, V.; Souza S. M. (2018). Technical-economic analysis for the integration of PV systems in Brazil considering policy and regulatory issues. Energy Policy 115, 199 - 206.

Instituto Nacional de Meteorologia (INMET). Normais Climatológicas do Brasil. Período de 1981 a 2010. Monthly and Annual Total Insulation Worksheet.

International Energy Agency (IEA). (1995). Task 16 Photovoltaics in Buildings. A Design Handbook for Architects and Engineers. XYZ Publishing Company. Freiburg (Germany).

International Energy Agency (IEA). (2010). Task 41 Solar Energy and Architecture. Subtask B: Methods and Tools. State-of-the-Art of Digital Tools Used by Architects for Solar Desgn. Solar Heating \& Cooling Programme International Energy Agency.

Jayathissa, P.; Schmidli, J.; Hofer, J.; Schlueter, A. (2016). Energy Performance of PV Modules as Adaptive Building Shading Systems. Proceedings from EU PVSEC: European Photovoltaic Solar Energy Conference. Munich (Germany), June 2016.

Nobre, André Maia. (2015). Short-term solar irradiance forecasting and photovoltaic systems performance in a tropical climate in Singapore. Doctorate degree thesis - Universidade Federal de Santa Catarina, Centro Tecnológico. Programa de Pós-Graduação em Engenharia Civil. Florianópolis (Brazil) 2015.

Oliveira, Natália P. R. de; Amorim, Cláudia N. D. (2017). Características arquitetônicas de edifícios comerciais no Plano Piloto - mapeamento do potencial de qualidade ambiental e desempenho energético. Proceedings from XXIII Congresso de Iniciação Científica - Universidade de Brasília. Brasília (Brazil), 2017.

Rüther, R; Zilles, R. (2011). Making the case for gridconnected photovoltaics in Brazil. Energy Policy 39, 1027 - 1030. 